\title{
Effects of dietary protein and fat level on oxidative phosphorylation in rat heart mitochondria
}

\author{
BY MASAAKI TOYOMIZU* AND M. THOMAS CLANDININ $\dagger$ \\ Nutrition and Metabolism Research Group, Departments of Foods \& Nutrition and Medicine, \\ University of Alberta, Edmonton, Alberta T6G 2C2, Canada
}

(Received 8 July 1991-Accepted 12 March 1992)

\begin{abstract}
The effect of dietary protein and fat levels on cardiac mitochondrial oxidative phosphorylation was assessed polarographically. Weanling rats were fed on semi-purified diets containing different protein levels (10, 30, 50 and 70\%) on a gross energy basis (PGE) for 9, 23 and $58 \mathrm{~d}$. Cardiac mitochondria isolated from rats fed on a $70 \%$ PGE diet for $23 \mathrm{~d}$ exhibited significantly reduced ADP:oxygen (ADP:O) values compared with mitochondria from rats fed on a low-protein diet. Feeding low-protein diets for $58 \mathrm{~d}$ increased the ADP: $O$ value. When the dietary fat level was altered to provide (\% PGE: \% fat-energy): 30:14, 30:30, 70:14, 70:30, feeding 70\% PGE diets reduced the ADP: $O$ value compared with the $30 \%$ PGE level, but no difference was observed between low-fat and high-fat groups. These results indicate that the impaired ADP:O value for rats fed on very-high-protein diets was not due to the dietary fat level but that the level of dietary protein is an important determinant of oxidative phosphorylation in rat heart mitochondria.
\end{abstract}

Protein intake: Fat intake: Oxidative phosphorylation: Rat

Treatment of morbid obesity often involves the use of high-protein, very-low-energy diets (Schemmel et al. 1983). Some biological responses to high-protein diets have been investigated. When animals were fed on a high-protein diet, fasting blood glucose and plasma insulin concentrations were significantly elevated in rats (Usami et al. 1982) and the absolute rate of whole-body protein synthesis decreased in chicks (Kita et al. 1989). Stereological analysis of ultrathin sections illustrated that the high-protein diet induced a significant increment in the density and size of hepatocyte mitochondria (Zaragoza et al. 1987). However, little is known regarding the effect of high-protein diets on bioenergetic function or mitochondrial function. In the present study two experiments were undertaken: the first experiment involved clarifying the effect of dietary protein level on oxidative phosphorylation of cardiac mitochondria, while the second study was designed to determine whether or not the impaired oxidative phosphorylation of rats fed on highprotein diets would be improved by addition of dietary fat.

\section{MATERIALS AND METHODS}

Animals and diets. Male Sprague-Dawley Weanling rats obtained from the University of Alberta at 3 weeks of age (52 (SE 3) g) were housed individually under a controlled $12 \mathrm{~h}$ light-dark cycle at $21 \pm 1^{\circ}$. After a $6 \mathrm{~d}$ adaptation period, animals were fed on a semi-

* Present address: Animal Nutrition, Faculty of Agriculture, Niigata University, 2-8050 Ikarashi, Niigata 95021, Japan.

$\dagger$ For reprints. 
Table 1. Composition of experimental diets $(\mathrm{g} / \mathrm{kg})$

\begin{tabular}{|c|c|c|c|c|c|c|c|c|}
\hline & \multicolumn{4}{|c|}{ Expt 1} & \multicolumn{4}{|c|}{ Expt 2} \\
\hline & $10 \%$ PGE & $30 \%$ PGE & $50 \%$ PGE & $70 \%$ PGE & MPLF & MPHF & HPLF & HPHF \\
\hline Casein & $68 \cdot 5$ & $220 \cdot 3$ & 395.9 & $601 \cdot 4$ & $220 \cdot 3$ & 247.6 & $601 \cdot 4$ & $690 \cdot 3$ \\
\hline Fat* & $53 \cdot 4$ & $57 \cdot 3$ & $61 \cdot 8$ & $67 \cdot 0$ & $57 \cdot 3$ & $138 \cdot 0$ & 67.0 & $164 \cdot 9$ \\
\hline Dextrose & $518 \cdot 4$ & $409 \cdot 7$ & $284 \cdot 0$ & $37 \cdot 0$ & $409 \cdot 7$ & $328 \cdot 8$ & $136 \cdot 9$ & $0 \cdot 0$ \\
\hline Maize starch & $259 \cdot 2$ & $204 \cdot 8$ & $142 \cdot 0$ & 68.5 & $204 \cdot 8$ & 164.4 & 68.5 & 0.0 \\
\hline Cellulose & $37 \cdot 3$ & $40 \cdot 0$ & $43 \cdot 1$ & $46 \cdot 8$ & $40 \cdot 0$ & $45 \cdot 0$ & $46 \cdot 8$ & $53 \cdot 7$ \\
\hline Vitamin Mix $\dagger$ & $8 \cdot 4$ & $9 \cdot 0$ & $9 \cdot 7$ & $10 \cdot 5$ & 9.0 & $10 \cdot 1$ & 10.5 & $12 \cdot 1$ \\
\hline Mineral Mix & $45 \cdot 4$ & $48 \cdot 7$ & $52 \cdot 5$ & $57 \cdot 0$ & $48 \cdot 7$ & $54 \cdot 8$ & $57 \cdot 0$ & $65 \cdot 4$ \\
\hline Choline & $2 \cdot 3$ & $2 \cdot 5$ & $2 \cdot 7$ & $2 \cdot 9$ & $2 \cdot 5$ & 2.8 & 2.9 & $3 \cdot 3$ \\
\hline Inositol & $5 \cdot 3$ & 5.6 & $6 \cdot 1$ & 6.6 & $5 \cdot 6$ & $6 \cdot 3$ & $6 \cdot 7$ & 7.6 \\
\hline L-methionine & 1.9 & $2 \cdot 0$ & $2 \cdot 2$ & $2 \cdot 4$ & $2 \cdot 0$ & $2 \cdot 3$ & $2 \cdot 4$ & $2 \cdot 7$ \\
\hline \multicolumn{9}{|c|}{ On gross energy basis: } \\
\hline$\% \mathrm{PGE}$ & $10 \cdot 0$ & $30 \cdot 0$ & $50 \cdot 0$ & $70-0$ & $30 \cdot 0$ & $30 \cdot 0$ & $70 \cdot 0$ & $70 \cdot 0$ \\
\hline$\% \mathrm{FGE}$ & 140 & 140 & 140 & $14 \cdot 0$ & 140 & 300 & 140 & $30 \cdot 0$ \\
\hline$\%$ CGE & $76 \cdot 0$ & 56.0 & 36.0 & 160 & 560 & $40 \cdot 0$ & 160 & 0.0 \\
\hline
\end{tabular}

$\% \mathrm{PGE}, \% \mathrm{FGE}$ and $\% \mathrm{CGE}$, percentage gross energy from dietary protein, fat and carbohydrate respectively; MPLF, medium-protein low-fat diet; MPHF; medium-protein high-fat diet; HPLF, high-protein low-fat diet; HPHF, high-protein high-fat diet.

* Fat consisted of a 80:13:7 (by wt) mixture of beef tallow, safflower oil and linseed oil.

$\uparrow$ Robblee \& Clandinin (1984).

$\$$ The mixture (Robblee \& Clandinin, 1984) was modified to add $6.33 \mathrm{~g} \mathrm{~K}_{2} \mathrm{HPO}_{4}, 52 \mathrm{mg} \mathrm{MnSO} . \mathrm{H}_{2} \mathrm{O}$ to $100 \mathrm{~g}$ mixture.

purified experimental diet (Table 1) and water ad lib. Body weight was recorded weekly and food intake was recorded every 2 or $3 \mathrm{~d}$. Gross energy provided by carbohydrate, fat and protein was determined by bomb calorimetry to be $14 \cdot 7,39 \cdot 5$ and $22 \cdot 0 \mathrm{~kJ} / \mathrm{g}$ respectively. All diets contained the same amounts of cellulose, minerals and vitamins per $100 \mathrm{~kJ}$ energyyielding nutrients. In Expt 1 four experimental diets of 10, 30 (standard diet), 50 and $70 \%$ protein-energy (PGE) level were formulated on a gross energy (GE) basis by substituting the carbohydrate level (CGE) at a constant fat (FGE) level (Table 1). In Expt 2 four experimental diets providing medium-protein-low-fat (MPLF), medium-protein-high-fat (MPHF), high-protein-low-fat (HPLF), and high-protein-high-fat (HPHF) were formulated on a GE basis by substituting protein and fat for carbohydrate (Table 1).

Measurement of mitochondrial respiration. Four rats from each group were killed by cervical dislocation at 9,23 and $58 \mathrm{~d}$ of feeding in Expt 1 . Twelve rats from each group were killed at $23 \mathrm{~d}$ of feeding in Expt 2 . Hearts were immediately excised for mitochondrial isolation (Clandinin, 1978). The purity and stability of these mitochondrial preparations have been characterized (Clandinin, 1978). Oxidation rates of isolated mitochondria were measured polarographically at $37^{\circ}$ using an $\mathrm{O}_{2}$ monitor. Rates of utilization, expressed in $\mathrm{ng} \mathrm{O}_{2} / \mathrm{mg}$ mitochondrial protein per min were measured with $10 \mathrm{~mm}$-pyruvate, $2 \mathrm{~mm}$ malate and $10 \mathrm{~mm}$-malonate as substrates for oxidative phosphorylation in the reaction mixture described previously by Clandinin (1978). The ADP concentration was determined spectrophotometrically (Jaworek et al. 1974). Respiratory rates, respiratory control indices and ADP:O ratios were calculated according to Chance \& Williams (1956). Protein was measured by a calorimetric method (Lowry et al. 1951).

Statistical procedures. The effect of treatment on mitochondrial functions was first examined by two-way analysis of variance to separate the effect of dietary protein level from the effect due to the duration of feeding in Expt 1. The effect of dietary protein and 
fat levels was similarly examined in Expt 2 with a statistical package SAS (Statistical Analysis System Institute, 1992). Significance level for individual group comparisons was $P<0.05$ using Duncan's least significant difference multiple-range test (Statistical Analysis System Institute, 1992).

\section{RESULTS AND DISCUSSION}

Body-weight gain for rats fed on 10 and $70 \%$ PGE diets for 23 and $58 \mathrm{~d}$ was lower than that for rats fed on a $30 \%$ PGE diet (Expt 1, Table 1). Rats fed on high-protein diets grew at a slower rate than rats fed on medium-protein diets, particularly for animals fed on highfat diets (Expt 2). No significant effect of dietary protein on energy consumption was observed, but rats fed on the medium-protein high-fat diet consumed more than animals fed on the medium-protein low-fat diet. These findings support those of Expt 1 and earlier observations with mice fed on diets of different protein levels (Toyomizu et al. 1988) and fat levels (Toyomizu et al. 1991).

The rate of $\mathrm{O}_{2}$ uptake and ADP:O ratio observed (Table 2) were similar to those previously reported (Clandinin, 1978, 1979). Determination of mitochondrial respiration did not indicate a difference in state 3 or state $4 \mathrm{O}_{2}$ uptake rate and ATP synthesized between either rats fed on diets of different protein levels for 9,23 or $58 \mathrm{~d}$, or between rats fed on diets of different fat levels. These results indicate that the oxidative rate is not affected by dietary protein and fat levels.

The ADP: $O$ ratio was not significantly different for mitochondria isolated from rats for all treatments after $9 \mathrm{~d}$ of feeding (Fig. 1(A)). The reduction in ADP:O ratio after feeding diets for $23 \mathrm{~d}$ was significant for animals fed on a $70 \%$ PGE diet compared with groups fed on the lower-protein diets (10,30 or $50 \%$ PGE). Mitochondria isolated from rats fed on a $10 \%$ PGE diet for $58 \mathrm{~d}$ exhibited an increased ADP:O ratio compared with rats fed on the higher-protein diets.

Most investigations of the proton stoichiometries of oxidative phosphorylation have ignored dietary effects. However, the effect of dietary composition on bioenergetic function is important since uncoupling of mitochondrial oxidative phosphorylation progressively decreases metabolic energy available from protein and fat relative to that available from glucose (Livesey, 1984). Little study has been done on the effects of excess dietary protein on mitochondrial function, although responses to a protein-deficient diet (Williams, 1971) and an essential fatty acid-deficient diet (Rafael et al. 1984) were examined. The present results show that the level of dietary protein is an important determinant of oxidative phosphorylation in rat heart mitochondria.

Dietary fat level as well as fat sources also affect bioenergetic function in mitochondria. Rats fed on a diet containing very-long-chain fatty acids show a decline in the oxidation of substrates at coupling sites I and II as well as a decrease in ATP synthesis in heart mitochondria associated with changes in composition of mitochondrial structure (Clandinin, 1978). Dietary fat level and the polyunsaturated: saturated fatty acid ratio alter ATPase (EC 3.6.1.34) activity in cardiac mitochondria and change mitochondrial structure (Robblee \& Clandinin, 1984). Therefore, we investigated whether the reduced oxidative phosphorylation in mitochondria of rats fed on a high-protein diet is altered by increasing dietary fat content.

Mitochondria from rats fed on high-protein diets for $23 \mathrm{~d}$ showed significantly reduced ADP: $O$ ratios when compared with medium-protein diets, but the impaired ADP:O ratio of rats fed on the high-protein diet was not improved by addition of dietary fat (Fig. 1(B)). To the authors' knowledge, virtually no information is available to confirm a direct effect of the amount of carbohydrate on mitochondrial functions. Earlier studies demonstrated that although fatty acid compositional differences were observed in hepatic mitochondria 
Table 2. Expts 1 and 2. Cumulative feed consumption, body-weight gain and oxidative activity of isolated cardiac mitochondria, with pyruvate and malate as substrate, from rats fed on diets of different levels of dietary protein and fat $\dagger$

\begin{tabular}{|c|c|c|c|c|c|c|c|}
\hline \multirow[b]{2}{*}{ Diet } & \multirow{2}{*}{$\begin{array}{l}\text { Duration } \\
\text { of } \\
\text { feeding } \\
\text { (d) }\end{array}$} & \multirow{2}{*}{$\begin{array}{c}\text { Feed } \\
\text { consumption } \\
(\mathrm{MJ})\end{array}$} & \multirow{2}{*}{$\begin{array}{l}\text { Body-wt } \\
\text { gain } \\
(\mathrm{g})\end{array}$} & \multicolumn{2}{|c|}{$\begin{array}{l}\text { Oxygen uptake rates } \\
\text { (ng atom/min per } \\
\text { mg protein) }\end{array}$} & \multirow{2}{*}{$\begin{array}{c}\text { ATP } \\
\text { synthesized } \\
\text { (nmol/ } \\
\text { min per mg } \\
\text { protein) }\end{array}$} & \multirow{2}{*}{$\begin{array}{l}\text { Respiratory } \\
\text { control } \\
\text { index } \|\end{array}$} \\
\hline & & & & State 3 & State 4 & & \\
\hline \multicolumn{8}{|l|}{$\begin{array}{l}\text { Expt } 1+9 \\
\% \text { PGE }\end{array}$} \\
\hline 10 & 9 & $2 \cdot 2$ & $40 \cdot 7^{\mathrm{b}}$ & 585 & 151 & 1400 & 3.92 \\
\hline 30 & 9 & $2 \cdot 4$ & $66 \cdot 9^{a}$ & 658 & 186 & 1590 & $3 \cdot 64$ \\
\hline 50 & 9 & $2 \cdot 21$ & $62 \cdot 6^{a}$ & 593 & 164 & 1500 & $3 \cdot 66$ \\
\hline 70 & 9 & $2 \cdot 18$ & $59 \cdot 7^{a}$ & 586 & 171 & 1380 & $3 \cdot 52$ \\
\hline \multicolumn{8}{|l|}{$\%$ PGE } \\
\hline 10 & 23 & $6 \cdot 48$ & $109^{b}$ & 551 & 138 & 1350 & 3.99 \\
\hline 30 & 23 & 6.93 & $166^{a}$ & 527 & 126 & 1280 & $4 \cdot 20$ \\
\hline 50 & 23 & $6 \cdot 51$ & $159^{\mathrm{a}}$ & 541 & 146 & 1310 & 374 \\
\hline 70 & 23 & 6.67 & $137^{a b}$ & 521 & 139 & 1190 & 3.78 \\
\hline \multicolumn{8}{|l|}{$\%$ PGE } \\
\hline 10 & 58 & $18 \cdot 86$ & $284^{b}$ & 546 & 144 & 1410 & 3.82 \\
\hline 30 & 58 & $20 \cdot 72$ & $359^{\mathrm{a}}$ & 593 & 165 & 1440 & $3 \cdot 61$ \\
\hline 50 & 58 & $19 \cdot 43$ & $321^{\mathrm{ab}}$ & 585 & 152 & 1430 & 3.88 \\
\hline 70 & 58 & $20 \cdot 38$ & $327^{a b}$ & 664 & 168 & 1510 & 395 \\
\hline Pooled SE & & & & $39 \cdot 4$ & $12 \cdot 8$ & 103 & 0.227 \\
\hline \multicolumn{8}{|l|}{$\begin{array}{l}\text { Statistical } \\
\text { significance of: }\end{array}$} \\
\hline Diet & & - & $\ldots$ & NS & NS & NS & NS \\
\hline Days & & - & - & $*$ & $* *$ & $*$ & NS \\
\hline Diet $x$ days & & - & - & NS & NS & NS & NS \\
\hline \multicolumn{8}{|l|}{ Expt $2 \S \Phi$} \\
\hline MPLF & 23 & $7 \cdot 20^{\mathrm{b}}$ & $164^{\mathrm{a}}$ & 462 & 147 & 1110 & $3 \cdot 16$ \\
\hline MPHF & 23 & $7 \cdot 63^{\mathrm{a}}$ & $170^{\mathrm{a}}$ & 480 & 150 & 1160 & $3 \cdot 21$ \\
\hline HPLF & 23 & $7 \cdot 40^{\mathrm{ab}}$ & $159^{a b}$ & 463 & 159 & 1030 & $2 \cdot 93$ \\
\hline HPHF & 23 & $7 \cdot 42^{\mathrm{ab}}$ & $149^{h}$ & 475 & 151 & 1060 & $3 \cdot 15$ \\
\hline Pooled SE & & 0.129 & 3.96 & 25.8 & $8 \cdot 18$ & $60 \cdot 4$ & 0.132 \\
\hline \multicolumn{8}{|l|}{$\begin{array}{l}\text { Statistical } \\
\text { significance of: }\end{array}$} \\
\hline PGE & & NS & $* * *$ & NS & NS & NS & NS \\
\hline FGE & & $*$ & NS & NS & NS & NS & NS \\
\hline $\mathrm{PGE} \times \mathrm{FGE}$ & & $*$ & $* *$ & NS & NS & NS & NS \\
\hline
\end{tabular}

$\%$ PGE and \% FGE, percentage gross energy from dietary protein and fat; MPLF, medium-protein low-fat diet; MPHF, medium-protein high-fat diet; HPLF, high-protein low-fat diet; HPHF, high-protein high-fat diet; NS, not significant.

${ }^{\text {ab }}$ Differences between individual means were analysed by Duncan's multiple-range test. Mean values with unlike superscript letters were significantly different $(P<0.05)$ :

$* P<0 \cdot 10, * * P<0 \cdot 05, * * * P<0 \cdot 01$.

$\dagger$ For details of diets, see Table 1 .

$\ddagger$ Mean values for four rats.

$\S$ Mean values for twelve rats for growth data, and for six samples of two pooled hearts for $\mathrm{O}_{2}$ consumption data.

$\|$ Calculated as state 3 : state 4 oxidation rates.

If Expt 1 df 36 for state 3 and state $4 \mathrm{O}_{2}$ uptake rates, for ATP synthesized and for respiratory control index. Expt $2 \mathrm{df} 44$ for feed consumption and body-weight gain, and 20 for state 3 and $4 \mathrm{O}_{2}$ uptake rates, for ATP synthesis and for respiratory control index. 

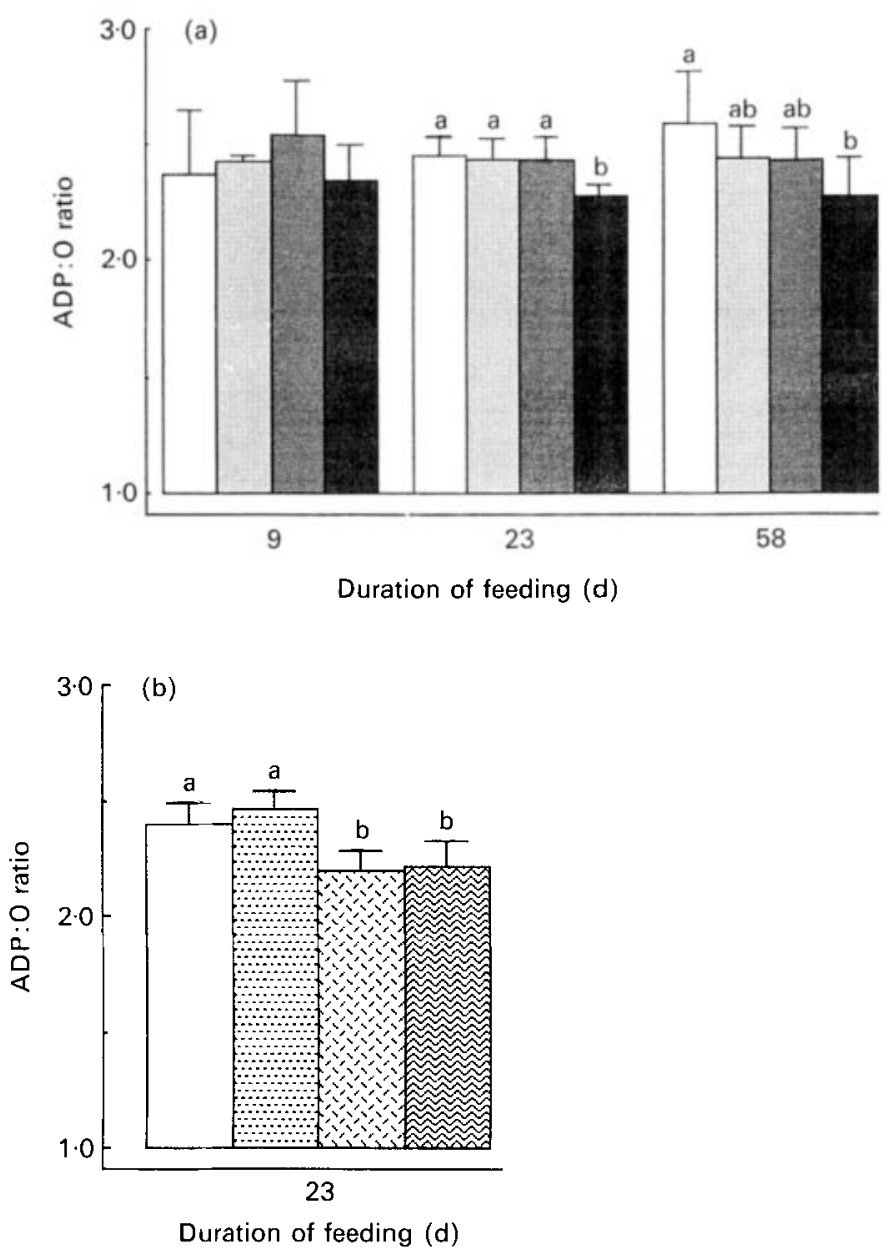

Fig. 1. Expts 1 and 2. Responses of ADP:oxygen (ADP:O) ratio to (a) dietary protein level (\% PGE; percentage gross energy from protein) at different feeding periods (Expt 1), and (b) dietary fat level (medium protein (MP), high protein (HP), high fat (HF), low fat (LF); Expt 2) in rat heart mitochondria. Expt 1:( $\square), 10 \%$ PGE; (圈), 30\%

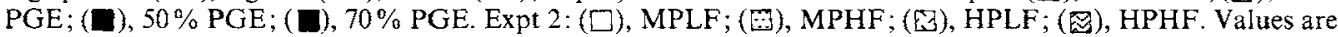
means for four rats (Expt 1) and for six samples of two pooled hearts (Expt 2) in each group with their standard errors represented by vertical bars. Differences in means were tested by Duncan's multiple-range test. Means with the same superscript letter for the same duration of feeding were not significantly different $(P<0.05)$. Pooled SE were 0.079 ( $\mathrm{df} 36$ ) and 0.037 ( $\mathrm{df} 20$ ) for Expts 1 and 2 respectively. For details of diets, see Table 1.

of rats fed on a $650 \mathrm{~g}$ sucrose $/ \mathrm{kg}$ or a $650 \mathrm{~g}$ maize starch $/ \mathrm{kg}$ diet, these differences had little effect on the membrane-associated, succinate-supported respiration in liver (Wander \& Berdanier, 1985). The present study showed no change in ADP:O ratio when dietary fat was substituted for carbohydrate. These results imply that carbohydrate sources or levels do not affect mitochondrial respiration. Therefore, it may be concluded that change in ADP : $O$ ratio in the present study was mainly due to changes in dietary protein rather than fat or carbohydrate level. However, the mechanism involved in this effect of protein remains to be clarified.

This research was supported by a grant in aid of research from the Natural Science and Engineering Research Council of Canada. M.T.C. is a Scholar of the Alberta Heritage 
Foundation for Medical Research. The authors gratefully acknowledge the technical assistance of A. Wierzbicki in fatty acid analysis. The valuable assistance of S. Goruk and T. Wharton is also greatly appreciated.

\section{REFERENCES}

Chance, B. \& Williams, G. R. (1956). The respiratory chain and oxidative phosphorylation. Advances in Enzymology 17, 65-134.

Clandinin, M. T. (1978). The role of dietary long chain fatty acids in mitochondrial structure and function. Effects on rat cardiac mitochondrial respiration. Journal of Nutrition 108, 273-281.

Clandinin, M. T. (1979). Effect of dietary long chain fatty acids on energy transport in cardiac mitochondria. FEBS Letters 102, 173-176.

Jaworek, B., Gruber, W. \& Bergmeyer, H. U. (1974). Adenosine-5'-diphosphate and adenosine-5'-monophosphate. In Methods of Enzymatic Analysis, pp. 2127-2131 [H. U. Bergmeyer, editor]. New York, NY: Academic Press.

Kita, K., Muramatsu, T. \& Okumura, J. (1989). Influence of excess protein intake on whole-body protein synthesis in chicks. Nutrition Reports International 39, 1091-1097.

Livesey, G. (1984). The energy equivalents of ATP and the energy values of food proteins and fats. British Journal of Nutrition 51, 15-28.

Lowry, O. H., Rosebrough, N. J., Farr, A. L. \& Randall, R. (1951). Protein measurement with the folin phenol reagent. Journal of Biological Chemistry 193, 265-275.

Rafael, J., Patzelt, J, Schafer, H. \& Elmadfa, I. (1984). The effect of essential fatty acid deficiency on basal respiration and function of liver mitochondria in rats. Journal of Nutrition 114, 255-262.

Robblee, N. M. \& Clandinin, M. T. (1984). Effect of dietary fat level and polyunsaturated fatty acid content on the phospholipid composition of rat cardiac mitochondrial membranes and mitochondrial ATPase activity. Journal of Nutrition 114, 263-269.

Statistical Analysis System Institute. SAS User's Guide: Statistics, version 6. Cary, NC, USA: SAS Institute Inc.

Schemmel, R. A., Stone, M., Warten, M. J. \& Stoddart, K. A. (1983). Nitrogen and protein losses in rats during weight reduction with a high protein, very low energy diet or fasting. Journal of Nutrition 113, 727-734.

Toyomizu, M., Hayashi, K., Yamashita, K. \& Tomita, Y. (1988). Response surface analyses of the effects of dietary protein on feeding and growth patterns in mice from weaning to maturity. Journal of Nutrition 118 , 86-92.

Toyomizu, M., Matsukubo, M., Hayashi, K. \& Tomita, Y. (1991). Response surface analyses of the effects of dietary fat on feeding and growth patterns in mice from weaning to maturity. Animal Production 52, $207-214$.

Usami, M., Seino, Y., Seino, S., Takemura, J., Nakahara, H., Ideka, M. \& Imura, H. (1982). Effects of high protein diet on insulin and glucagon secretion in normal rats. Journal of Nutrition 112, 681-685.

Wander, R. C. \& Berdanier, C. D. (1985). Effects of dietary carbohydrate on mitochondrial composition and function in two strains of rats. Journal of Nutrition 115, 190-199.

Williams, J. N. Jr (1971). Response of oxidative phosphorylation in rat liver to prolonged protein depletion. Journal of Nutrition 101, 981-988.

Zaragoza, R., Renau-Piqueras, J., Portoles, M., Hernandez-Yago, J., Jorda, A. \& Grisolia, S. (1987). Rats fed prolonged high protein diets show an increase in nitrogen metabolism and liver megamitochondria. Archives of Biochemistry and Biophysics 258, 426435. 